\title{
Exploration on the Special Talents of Environmental Engineering Based on Engineering Professional Accreditation
}

\author{
Yunfen Shi ${ }^{1, a^{*}}$, Meitong $\mathrm{Jin}^{2, \mathrm{~b}}$ and Difei $\mathrm{Qu}^{3, \mathrm{c}}$
}

School of Chemical engineering, Northeast Electric Power University Jilin Jilin 132012, China

ashiyunfen0220@163.com,,842820664@qq.com,c1106989110@qq.com

Keywords: Professional; Designation; Environmental engineering; Characteristic specialty construction

Abstract. Aiming at training talents with engineering capability for environment major, propose establishing a comprehensive cultivating system that have curriculum groups and a practice teaching system with engineering background under the guidance of foster plan on building the connotation of engineering capability and keep forging a teaching team of high quality as well as innovating the traditional teaching and testing patterns as ensuring measures.

\section{Introduction}

Professional characteristic of education in colleges and universities is not only an important initiative to improve teaching quality, but also the fundamental path to construct brands and develop the connotation [1]. The guidance of ability is the foothold of characteristics of professional construction. And characteristics of professional construction are to establish some ordered, steady, and continuous activity based on the requirements of graduates quality.

China was accepted as the preparatory member of Washington Agreement by the unanimous consent of International Union of Engineering officially on June $19^{\text {th }}, 2013$. And this will have a huge influence and promotion on the reform of higher education in China. Engineering education certification is recognition of various types of engineering and technical education quality, which are set up by colleges and universities, from engineering practice and professional points of view. According to the certification, the professional quality of education has reached the required level, the graduates have mastered the necessary theoretical, technical, industrial and social knowledge to engage in engineering technology.

\section{Current Status of Environmental Engineering Certification}

The environmental engineering specialty was added to the engineering education professional certification pilot professional in 2007. Kunming University of Science and Technology, Wuhan University, South China University of Technology, East China University of Science and Technology, and Beijing University of and Technology are the first batch of certified environmental engineering schools in 2014. At present, there are 366 colleges and universities in the country who have established environmental engineering major. 22 of them have passed the environmental engineering certification, and only Kunming University of Science and Technology is not 985 or 211.

For example, Jiangsu University takes the agriculture as a heavy foundation, adheres the school of thought that "to promote the specialty construction by discipline construction, to promote talents training with scientific research, to develop from the perspective of innovation, to create a brand with a feature, to survive with quality", takes people as a basic, fully mobilizes the enthusiasm of students and teachers teaching reform enthusiasm [2]. Through the unremitting efforts, the professional initially form its own characteristics and advantages in the agricultural environmental protection, environmental protection equipment, green oxidation technology and other aspects. [3] 


\section{Talent Training}

Aim of Talents Training. The Environmental Engineering Department of Tohoku Electric Power University takes full advantage of its favorable resources and insists that the environmental engineering specialty be closely integrated with the actual production process. It mainly cultivates professional talents with engineering practice ability and innovation ability, with the power industry and social environmental protection department as the main service targets. [4]

Development of Training Programs. Environmental engineering of Northeast Electric Power University explores and optimizes the environmental engineering talent training programs, theoretical courses and practical curriculum system according to the power industry on the quality of the demand for talent [5]. In the training program and professional elective courses setting, it is necessary to face the social environmental protection departments, but also important to highlight the field of power plant environmental engineering industry characteristics.

Implementation of Training Programs. Strengthening the basic. The School of Environmental Engineering has always attaching importance to basic education, and has built a "Water Pollution Control Engineering", "Analytical Chemistry" "Physical Chemistry" and other provincial and provincial excellent courses. Basic education has been the evaluation team of experts praise in the undergraduate teaching evaluation.

Optimizing the curriculum with the advantages of discipline. The professional built a strong teaching force of teachers, commitment and completed a number of National Natural Science Foundation of China, 863 projects, the Jilin Provincial Environmental Protection Department and other provincial and ministerial level scientific research projects, formed a strong academic advantage, relies on "environmental science and engineering" subject master [6]. In the professional basic courses and professional courses in classroom teaching, experimental teaching, curriculum design, comprehensive experiment and graduation project, the teaching content covers the thermal power plant production process of waste water, waste residue, waste gas, other background knowledge and needs of environmental engineering technology. At the same time, Teachers compile research projects in the success stories into teaching materials or handouts in a timely manner; bring the scientific research into classroom teaching, so that teaching level is improved.

Training ability in engineering practice. Our school has created the conditions for training engineering practice ability, relies on various types of practice inside and outside the school, practice base and other experimental teaching resources. Our school has created the conditions for training the ability of engineering practice, relies on various types of practice inside and outside the school, practice base and other experimental teaching resources of training engineering practical ability, and a training mode that make a combination of production, teaching, and research, underground the production of electricity and local environmental protection.

Some of the most distinctive, first, Water Treatment Engineering Laboratory, including the Jilin Petrochemical Wastewater, power plant desulfurization wastewater treatment and reuse of experimental devices. It can be carried out in the chemical process of sewage, power plant desulfurization wastewater treatment and resource utilization of the experiment and research. Second, Flue Gas Desulfurization and Denitrification Laboratory, including multi-component dynamic distribution system, dynamic flue gas composition detector, flue gas denitration catalyst evaluation system. Third, Environmental Microbiology Laboratory can be used to solve the problem of soil pollution caused by sewage sludge of Jilin Petrochemical Company, select high-efficiency biodegradable bacteria group, and construct microbial remediation technology of petrochemical pollution soil. Forth, Environmental Monitoring Laboratory, including analysis and monitoring of refractory organic pollutants in petrochemical wastewater, monitoring of petroleum components in petroleum-contaminated soils, and monitoring and analysis of volatile organic pollutants in petroleum refineries. Last, Solid Waste Recycling Laboratory can be used for power plant fly ash, corn straw resource utilization of the experiment and research. All of these laboratories and equipment are practical engineering practice, can be close to or consistent with the situation of production enterprises, and provide an experimental platform in order to promise the 
training in engineering practice ability of students.

Completing Engineering Practice Ability Training System. Through schools, enterprises, research institutes and the close integration of relevant departments, according to the requirements of power industry professionals on the quality of environmental engineering, we finally innovated and optimized the structural system of the practical courses and links of environmental engineering talents training; achieve the aim of "continuous engineering practice for four years without interruption". Freshman entered the basic laboratory, and carried out experimental skills training in the public basic experimental platform, combined with inorganic and analytical chemistry, organic chemistry courses. Sophomore entered the professional basic laboratory, carried out environmental chemistry and other professional basic experimental skills training. We encourage students to participate in experimental skills competitions, in order to improve their experimental and practical skills. Junior entered the professional laboratory and research laboratory, carried out a comprehensive curriculum design and other experiments, to improve their practical ability by recognizing internships. Senior students entered into the professional learning. They have improved their ability of engineering practice, through the professional comprehensive experiment, production practice [7], theory, practice and other aspects of the graduation project.

Creating a Platform for Teaching Students According to Their Aptitude, to Achieve the Principle of Teaching Students According to Their Aptitude. In the professional teaching process, for the outstanding students, we have excellent students tutor system, that means arranging for supervisors to instruct students to participate in the research process and stimulate their interest in learning. For hands-on students, we arrange for them to enter the laboratory to participate in the construction of the laboratory, to provide them with training opportunities for practical ability. For students with strong innovation ability, we encourage and guide them to participate in national energy-saving emission reduction, chemical design and other competitions [8]. For the foundation of the poor students, we arrange for a professional teacher to help a system in the course of teaching, ensure that students are not left behind. By these above measures, a total of 155 people access to technology awards in recent years.

\section{Characteristics of Personnel Training}

The employment rate of environmental engineering graduates in our school has reached more than 90\%. Their main employment directions are electric field, chemical enterprise environmental management department, environmental protection enterprises and government undertakings and research institutions. Some of them have become experts in the field of environmental engineering and senior technical experts, the employment situation are optimistic.

\section{Acknowledgment}

This work was supported in part by grants from the Teaching Reform of Undergraduate Course in Jilin Province (Higher Education Documents of Jilin Province No.[2016]32 and Teaching Reform of the Northeast Electric Power University in 2015 (JX201511).

\section{References}

[1] Y.J. Zhang, H.F. Zhang, and X.H. Sun, et al of the Exploring and Practice to Improve Quality of Graduation Project for Applied Chemistry Specialty [J], Journal Of Northeast Electric Power University (in Chinese), Vol. 33 (2013) No.4, p.97-99

[2] Y.G. Li, B. Yan, M.X. Zeng, H.Y. Fu, T. Chai and J.F. Liu of the Construction and Practice of Practical Education System of Applied Environmental Engineering [J], Experiment Science Technology (in Chinese), Vol. 9 (2011) No.3, p.105

[3] L.Y. Jiang and J. Chen of the Teaching Reform of Environmental Engineering Based on Environmental Professional Accreditation [J], Journal Of Zhejiang University Of Technology 
(Social Science)(in Chinese), Vol. 13 (2014) No.3, p.256

[4] Y.F. Shi, X.H. Xu, and L.D. Liu et al of the Professional Practice Mode on Environmental Engineering with Characteristics of Power Plant Environmental Protection [J], Journal Of Northeast Electric Power University (in Chinese), Vol. 33 (2013) No.4, p.88-90

[5] L.H. Zhang, Y.P. Jia, and Y.J. Zhang, et al of the Course Reform and Practice of Water Pollution Control Engineering [J], Journal Of Northeast Electric Power University (in Chinese), Vol. 33 (2013) No.4, p.82-84

[6] X.H. Zhang, X.Q. Lin and Z.H. Hu of the Research and Practice on Engineering Capability Cultivation for College Students of Environmental Sciences [J], Higher Education Forum (in Chinese), Vol. 4 (2009) No.4, p.3

[7] Q. Wei, Y.P. Jia, and S. Zheng, et al of the Biological Technology Comprehensive Experiment' s Teaching Reform and Practice Based on the Mode of Application Type Innovative Talents Training[J], Journal Of Northeast Electric Power University (in Chinese) Vol. 33 (2013) No.4, p.91-93

[8] Y.Y. Chen, G.H. Xu, X.L. Liu and S.Y. Yang of the Cultivate Practice Abilities of Students from the Major of Environmental Engineering through Self - Made Environmental Device [J], Experiment Science and Technology (in Chinese), Vol. 13 (2015) No.6, p.154 